\title{
Penerapan Fokus Group Discussian (FGD) Untuk Meningkatkan Kemampuan Memanfaatkan Lingkungan Sebagai Sumber Belajar
}

\author{
Made Waluyati \\ SD Negeri 1 Jinengdalem \\ sdlmadewaluyati@gmail.com
}

\author{
ARTICLELINFO \\ Article history: \\ 1 Januari 2020 Received in \\ revised form \\ 30 Mei 2020 \\ Accepted 30 Juni 2020 \\ Available online \\ 15 Juli 2020 \\ Kata Kunci: \\ FGD, lingkungan sebagai \\ sumber belajar \\ Keywords: \\ $F G D$, the ability to use the \\ environment as a source of \\ learning
}

\begin{abstract}
ABSTRAK
Salah satu penyebab kurang maksimalnya hasil belajar siswa adalah pola pembelajaran yang monoton dimana guru masih lebih memilih menggunakan model pembelajaran konvensional yang mana guru masih mendominasi proses pembelajaran. Agar hasil belajar siswa maksimal maka sangat penting bagi guru untuk terampil menciptakan pembelajaran inovatif dan bermakna. Salah satu langkah yang dapat dilakukan adalah menerapkan pendekatan PAKEM (Pembelajaran Aktif Kreatif dan Menyenangkan) dimana guru menghadapkan siswa dengan dunia nyata sesuai dengan yang dialaminya sehari-hari. Namun, melakanakan pembelajaran dengan menerapkan pendekatan PAIKEM dikalangan guru masih belum
\end{abstract} optimal. Penelitian ini adalah penelitian tindakan kelas yang bertujuan meningkatkan kemampuan guru dalam memanfaatkan lingkungan sebagai sumber belajar setelah penerapan Focus Group Discussion. Penelitian dilaksanakan selama dua siklus. Berdasarkan hasil analisis ditemukan bahwa penerapan fokus group discussian (FGD) dapat meningkatkan kemampuan guru dalam memanfaatkan lingkungan sebagai sumber belajar. Hal ini terlihat dari rata-rata kemampuan guru dalam memanfaatkan lingkungan sebagai sumber belajar pada prasiklus sebesar 65,19 sedangkan setelah dilaksanakan tindakan pada siklus I terjadi peningkatan nilai menjadi 70,37 dan semakin meningkat menjadi 78,52 pada siklus II. 


\section{PENDAHULUAN}

Sesuai Kurikulum 2013 yang berlaku sekarang ini, memerlukan strategi baru terutama dalam kegiatan pembelajaran. Pendekatan pembelajaran yang sebelumnya lebih banyak didominasi oleh peran guru (teacher centered) diperbaharui dengan sistem pembelajaran yang berpusat pada siswa (student centered). Dalam implementasinya guru harus mampu memilih dan menerapkan model, motode atau setrategi pembelajaran yang sesuai dengan karakteristik materi sehingga mampu mengembangkan daya nalar siswa secara optimal. Dengan demikian dalam pembelajaran guru tidak hanya terpaku dengan pembelajaran di dalam kelas, melainkan guru harus mampu melaksanakan pembelajaran dengan metode yang variatif. Salah satu pendekatan yang dapat digunakan dalam proses pembelajaran yaitu pendekatan PAKEM.

Berdasarkan pendekatan PAKEM (Pembelajaran Aktif Kreatif dan Menyenangkan), guru harus mampu menghadapkan siswa dengan dunia nyata sesuai dengan yang dialaminya sehari-hari. Penerapan pendekatan PAKEM akan menunjang keberhasilan dalam proses pembelajaran karena siswa diberikan kesempatan berpartisipasi aktif dalam merancang dan membuat karya sendiri. Putra dan Anton (2017) dalam penelitiannya menyatakan bahwa, dengan pendekatan PAKEM siswa dapat menambah pengalaman serta dapat menemukan solusi dari permasalahan yang ditemukan. Memanfaatkan lingkungan sebagai sumber belajar merupakan strategi yang dapat mengembangkan motivasi dan partisipasi siswa dalam pembelajaran. Hal tersebut sesuai dengan pendekatan contekstual yaitu masyarakat belajar (Siregar, 2018).

Siregar, dkk (2017) juga menyatakan pembelajaran PAKEM merupakan model pembelajaran kontenstual yang meliputi empat prinsip utama yaitu proses interaksi, komunikasi, refleksi, dan eksplorasi. Memanfaatkan lingkungan sekolah sebagai sumber belajar akan membelajarkan siswa mengenai berbagai fakta dalam kehidupan sehari-hari. Hal ini sejalan dengan penelitian yang dilakukan oleh Istialina (2016) yang menyatakan bahwa pemanfaatan lingkungan sekolah sebagai sumber belajar akan membuat siswa lebih aktif dan termotivasi dalam menggali pengetahuannya sehingga siswa tidak merasa bosan dalam pembelajaran. Ekowati (2001) juga menyatakan, memanfaatkan lingkungan sekolah sebagai sumber belajar merupakan bentuk pembelajaran yang berfihak pada pembelajaran melalui penggalian dan penemuan (experiencing) serta keterkaitan (relating) antara materi pelajaran dengan konteks pengalaman kehidupan nyata melalui kegiatan proyek. Dalam pembelajaran peserta didik tidak hanya berinteraksi dengan guru melainkan berinteraksi dengan sumber belajar untuk mencapai tujuan belajar (Supriadi, 2015). Guru bertindak sebagai pelatih matekognitif dalam pembelajaran ini, guru akan membantu menemukan materi belajar, kemudian siswa membuat laporan dan menampikan hasil laporan dalam bentuk presentasi.

Pada kenyataannya, selama ini masih banyak guru yang kurang memanfatkan lingkungan sekolah sebagai sumber belajar. Berdasarkan hasil observasi, lingkungan sekolah hanya digunakan sebagai tempat bermain bagi siswa selama istirahat. Selain itu, jika tidak terjadi proses pembelajaran didalam kelas, guru lebih cenderung mengajak siswa untuk tetap didalam kelas walaupun sebenarnya siswa sudah sangat jenuh didalam kelas. Guru hanya memanfaatkan lingkungan sekolah hanya berkisar dua hingga tiga kali dalam satu semester untuk proses pembelajaran. Guru lebih sering menyajikan pelajaran di dalam kelas walaupun materi yang disajikan berkaitan dengan lingkungan sekolah. Dari wawancara yang telah dilakukan, sebagian besar guru mengaku enggan mengajak 
siswa belajar di luar kelas, karena alasan susah mengawasi. Selain itu ada guru yang menyampaikan bahwa mereka tidak bisa dan tidak mengerti dalam memanfaatkan lingkungan sekolah sebagai sumber belajar.

Untuk mengatasi permasalahan tersebut, salah satu solusi yang dapat diberikan yaitu dengan menerapkan fokus group discussion (FGD). Hal ini sejalan dengan penelitian yang dilakukan oleh Bisjoe (2018) menyatakan bahwa metode FGD dapat memberikan data yang lebih mendalam, informati, dan bernilai, kemudian dari segi kepraktisan model ini hemat biaya, dan dapat mengumpulkan data lebih banyak dengan waktu yang singkat. Penelitian yang dilakukan oleh Aswat (2019:20) juga menyatakan bahwa "metode FGD dapat meningkatkan mengalami peningkatan kegiatan guru yang baik hingga berada pada kategori yang sangat baik". Widiyati (2019) dalam penelitiannya juga menyatakan bahwa penerapan FGD dapat meningkatkan aktivitas dan hasil belajar secara signifikan. Situmorang (2019:226) menyatakan bahwa "FGD berpengaruh terhadap uji kompetensi terhadap tingkat kecemasan mahasiswa yang menjadi rendah". FGD merupakan metode pemecahan masalah dengan menciptakan suasana kekeluargaan. Bisjoe (2018:18) menyatakan bahwa "FGD sebagai suatu proses pengumpulan data dan informasi kualitatif dengan cara sistematis mengenai suatu masalah yang dilakukan melalui diskusi kelompok". FGD mengandung tiga kata kunci yaitu diskusi, kelompok, dan terfokus/terarah (Siregar, 2019).

Saat diskusi, materi yang akan didiskusikan yaitu permasalahan yang sedang dihadapi, akan difokuskan dalam bentuk pertanyaan, tugas, dan pendapat yang harus disampaikan oleh peserta (Elfi, 2017). Dalam kegiatan diskusi tersebut para guru bisa membagi pengalaman dalam pemanfaatan lingkungan sekolah sebagai sumber belajar untuk mencapai hasil belajar yang optimal. Bagi guru yang tingkat pengalamannya tinggi akan menjadi lebih matang dan bagi guru yang tingkat pengalamannya rendah akan menambah pengetahuan. Keunggulan FGD adalah keterlibatan guru bersifat holistik dan konprehensip dalam semua kegiatan. Afiyanti (2008) juga menyatakan keunggulan penggunaan FGD lainnya yaitu memberikan data yang lebih banyak dan memberikan nilai tambah. Keunggulan lainnya yaitu guru dapat menukar pendapat, memberi saran, tanggapan dan berbagai reaksi sosial dengan teman seprofesi sebagai peluang bagi mereka untuk meningkatkan kemampuan dan pengalaman.

Berdasarkan uraian latar belakang di atas, perlunya penerapan Focus Group Discussion agar dapat meningkatkan kemampuan guru dalam memanfaatkan lingkungan sebagai sumber belajar. Diharapkan guru dapat terampil dalam menciptakan pembelajaran inovatif dan bermakna sehingga siswa termotivasi dalam belajar, dan hal tersebut akan berdampak pada tercapainya tujuan pembelajaran.

\section{METODE PENELITIAN}

Penelitian yang dilakukan termasuk penelitian tindakan. Menurut Agung (2010) penelitian tindakan adalah suatu bentuk penelitian refleksi diri yang dilakukan oleh para partisipan dalam situasi-situasi sosial untuk memperbaiki praktik yang dilakukan sendiri. Dengan demikian, akan diperoleh pemahaman yang komprehensif mengenai praktik dan situasi di mana praktik tersebut dilaksanakan. Prosedur penelitian sangat tergantung dari model penelitian tindakan yang diterapkan. 
Penelitian didahului dengan mengidentifikasi permasalahan berdasarkan kondisi nyata pada kemampuan guru dalam memanfaatkan lingkungan sebagai sumber belajar. Setelah permasalahan teridentifikasi langkah selanjutnya adalah menganalisis permasalahan dimaksud. Analisis masalah dipergunakan untuk merancang tindakan baik dalam bentuk spesifikasi tindakan, keterlibatan peneliti, waktu dalam satu siklus, indikator keberhasilan, peningkatan sebagai dampak tindakan, dan hal-hal yang terkait lainya dengan pemecahan yang diajukan.

Langkah selanjutnya setelah masalah dirumuskan secara operasional, dan telah dirumuskan pula alternatif tindakan yang akan diambil, maka kegiatan selanjutnya adalah merencanakan langkah-langkah tindakan berdasarkan alternatif tindakan yang diambil. Tahapan selanjutnya melaksanakan kegiatan FGD sesuai dengan yang telah direncanakan sebelumnya, selanjutnya diimplementasikan terhadap guru SD Negeri 1 Jinengdalem dalam pelaksanaan proses pembelajaran. Penerapan skenario tindakan dilaksanakan secara benar dan tampak berlaku secara alamiah wajar.

Tahapan pelaksanaan tindakan pada penelitian ini adalah membagi guru dalam dua kelompok kecil, peneliti memberi penjelasan tentang pemanfaatan lingkungan sekolah sebagai sumber belajar, guru menyusun skenario pembelajaran dengan memanfaakan lingkungan sekolah sebagai sumber belajar dalam diskusi kelompok, peneliti membimbing kelompok guru dalam menyusun RPP, Wakil kelompok guru mempresentasikan skenario pembelajaran, peneliti memberi masukan terhadap RPP yang telah dibuat kelompok guru, guru melaksanakan skenario pembelajaran dalam proses pembelajaran yang sebenarnya, peneliti mengevaluasi kemampuan guru dalam mengimplementasikan skenario pembelajaran, dan dalam kelompok diskusi guru berbagi pengalaman terkait dengan pelaksanaan pembelajaran yang memanfaakan lingkungan sekolah sebagai sumber belajar.

Tahap observasi berlangsung secara bersamaan pada saat pelaksanaan tindakan. Pengamatan dilakukan pada waktu tindakan sedang berjalan, keduanya berlangsung dalam waktu yang sama. Pada tahapan ini, peneliti melakukan pengamatan dan mencatat semua hal-hal yang diperlukan dan terjadi selama pelaksanaan tindakan berlangsung. Pengumpulan data ini dilakukan dengan menggunakan format observasi/penilaian yang telah disusun. Termasuk juga pengamatan secara cermat pelaksanaan skenario tindakan dari waktu ke waktu dan dampaknya terhadap kemampuan guru memanfaatkan lingkungan sebagai sumber belajar.

Tahap refleksi dimaksudkan untuk mengkaji secara menyeluruh tindakan yang telah dilakukan, berdasar data yang telah terkumpul, dan kemudian melakukan evaluasi guna menyempurnakan tindakan yang berikutnya. Refleksi dalam penelitian tindakan, mencakup analisis, sintesis, dan penilaian terhadap hasil pengamatan atas tindakan yang dilakukan. Refleksi bermanfaat untuk mengetahui tingkat keunggulan maupun kelemahan pelaksanaan tindakan yang direncanakan dari masing-masing siklus, sehingga dengan demikian berdasarkan hasil refleksi dapat diputuskan apakah siklus dilanjutkan atau dihentikan. Siklus dilanjutkan bisa karena hasilnya belum mencapai target yang ditentukan. Sedangkan dihentikan jika target telah terpenuhi atau sangat tidak mungkin untuk dilanjutkan. Pada prinsipnya hasil refleksi dipergunakan untuk menyempurnakan kelemahan-kelemahan pelaksanaan tindakan.

Penelitian ini dilakukan dalam 2 (dua) siklus karena pada siklus ke-2 hasil penelitian telah mencapai indikator keberhasilan. Tiap siklus dilaksanakan sebanyak 3 
kali pertemuan. Subjek penelitian ini adalah guru SD Negeri 1 Jinengdalem yang berjumlah 9 orang. Objek penelitian ini adalah kemampuan guru SD Negeri 1 Jiengdalem dalam memanfaatkan lingkungan sebagai sumber belajar. Penelitian ini dilakukan pada semester genap tahun pelajaran 2019/2020 yakni dari bulan Januari sampai dengan Maret 2020.

Data penelitian ini dikumpulkan dengan menggunakan metode pengamatan/ observasi terhadap kemampuan guru memanfaatkan lingkungan sebagai sumber belajar. Kemampuan guru memanfaatkan lingkungan sebagai sumber belajar akan terukur dari supervisi yang dilakukan. Jika kemampuan guru memanfaatkan lingkungan sebagai sumber belajar tinggi maka tentu saja nilai dokumen hasil kerja guru akan tinggi juga.

Instrumen yang digunakan dalam penelitian ini yang berupa instrumen penilaian kemampuan guru memanfaatkan lingkungan sebagai sumber belajar.

Tabel 01 Instrumen Penilaian Kemampuan Guru Memanfaatkan Lingkungan Sebagai Sumber Belajar

\begin{tabular}{|c|c|c|c|c|c|c|c|}
\hline \multirow{2}{*}{ No } & \multirow{2}{*}{ Aspek } & \multicolumn{5}{|c|}{ Skor } & \multirow{2}{*}{ Ket } \\
\hline & & 1 & 2 & 3 & 4 & 5 & \\
\hline 1 & $\begin{array}{l}\text { Hubungan materi pelajaran dengan } \\
\text { lingkungan sebagai sumber belajar }\end{array}$ & & & & & & \\
\hline 2 & $\begin{array}{l}\text { Kemampuan guru menghubungkan materi } \\
\text { ajar dengan lingkungan sebagai sumber } \\
\text { belajar }\end{array}$ & & & & & & \\
\hline 3 & $\begin{array}{l}\text { Keaktifan anak belajar dengan menggunakan } \\
\text { lingkungan sebagai sumber belajar }\end{array}$ & & & & & & \\
\hline 4 & $\begin{array}{l}\text { Kemampuan guru memilih lingkungan yang } \\
\text { akan dijadikan sebagai sumber belajar sesuai } \\
\text { dengan tujuan pembelajaran }\end{array}$ & & & & & & \\
\hline 5 & $\begin{array}{l}\text { Kemampuan guru membuka pelajaran } \\
\text { dengan menggunakan lingkungan sebagai } \\
\text { sumber belajar }\end{array}$ & & & & & & \\
\hline 6 & $\begin{array}{l}\text { Peningkatan hasil belajar siswa dengan } \\
\text { menggunakan lingkungan sebagai sumber } \\
\text { belajar }\end{array}$ & & & & & & \\
\hline
\end{tabular}

Tabel 02. Rubrik Penilaian Kemampuan Guru Memanfaatkan Lingkungan Sebagai Sumber Belajar

\begin{tabular}{|c|c|c|}
\hline No & Aspek & Rubrik \\
\hline 1 & $\begin{array}{l}\text { Hubungan materi pelajaran } \\
\text { dengan lingkungan sebagai } \\
\text { sumber belajar }\end{array}$ & $\begin{array}{l}\text { 1. Hubungan materi pelajaran dengan lingkungan } \\
\text { sebagai sumber belajar sangat jelas } \\
\text { 2. Hubungan materi pelajaran dengan lingkungan } \\
\text { sebagai sumber belajar jelas } \\
\text { 3. Hubungan materi pelajaran dengan lingkungan } \\
\text { sebagai sumber belajar cukup jelas } \\
\text { 4. Hubungan materi pelajaran dengan lingkungan } \\
\text { sebagai sumber belajar kurang jelas } \\
\text { 5. Hubungan materi pelajaran dengan lingkungan } \\
\text { sebagai sumber belajar tidak jelas }\end{array}$ \\
\hline
\end{tabular}




\begin{tabular}{l|l}
\hline No & \multicolumn{1}{|c}{ Aspek } \\
\hline 2 & $\begin{array}{l}\text { Kemampuan guru } \\
\text { menghubungkan materi ajar } \\
\text { dengan lingkungan sebagai } \\
\text { sumber belajar }\end{array}$ \\
Kemampuan guru memilih \\
kemampuan guru membuka \\
pelajaran dengan \\
menggunakan lingkungan \\
belajar sesuai dengan tujuan \\
Keaktifan anak belajar \\
dengan menggunakan \\
lingkungan sebagai sumber \\
belajar
\end{tabular}

1. Guru sangat mampu menghubungkan materi pelajaran dengan lingkungan sebagai sumber belajar

2. Guru mampu menghubungkan materi pelajaran dengan lingkungan sebagai sumber belajar

3. Guru cukup mampu menghubungkan materi pelajaran dengan lingkungan sebagai sumber belajar

4. Guru kurang mampu menghubungkan materi pelajaran dengan lingkungan sebagai sumber belajar

5. Guru tidak mampu menghubungkan materi pelajaran dengan lingkungan sebagai sumber belajar

1. Anak belajar dengan menggunakan lingkungan sebagai sumber belajar dengan sangat aktif

2. Anak belajar dengan menggunakan lingkungan sebagai sumber belajar dengan aktif

3. Anak belajar dengan menggunakan lingkungan sebagai sumber belajar dengan cukup aktif

4. Anak belajar dengan menggunakan lingkungan sebagai sumber belajar dengan kurang aktif

5. Anak belajar dengan menggunakan lingkungan sebagai sumber belajar dengan tidak aktif

1. Guru sangat mampu memilih lingkungan yang akan dijadikan sebagai sumber belajar sesuai dengan tujuan pembelajaran

2. Guru mampu memilih lingkungan yang akan dijadikan sebagai sumber belajar sesuai dengan tujuan pembelajaran

3. Guru cukup mampu memilih lingkungan yang akan dijadikan sebagai sumber belajar sesuai dengan tujuan pembelajaran

4. Guru kurang mampu memilih lingkungan yang akan dijadikan sebagai sumber belajar sesuai dengan tujuan pembelajaran

5. Guru tidak mampu memilih lingkungan yang akan dijadikan sebagai sumber belajar sesuai dengan tujuan pembelajaran

1. Guru sangat mampu membuka pelajaran dengan menggunakan lingkungan sebagai sumber belajar 


\begin{tabular}{|c|c|c|}
\hline No & Aspek & Rubrik \\
\hline 6 & $\begin{array}{l}\text { Peningkatan hasil belajar } \\
\text { siswa dengan menggunakan } \\
\text { lingkungan sebagai sumber } \\
\text { belajar }\end{array}$ & 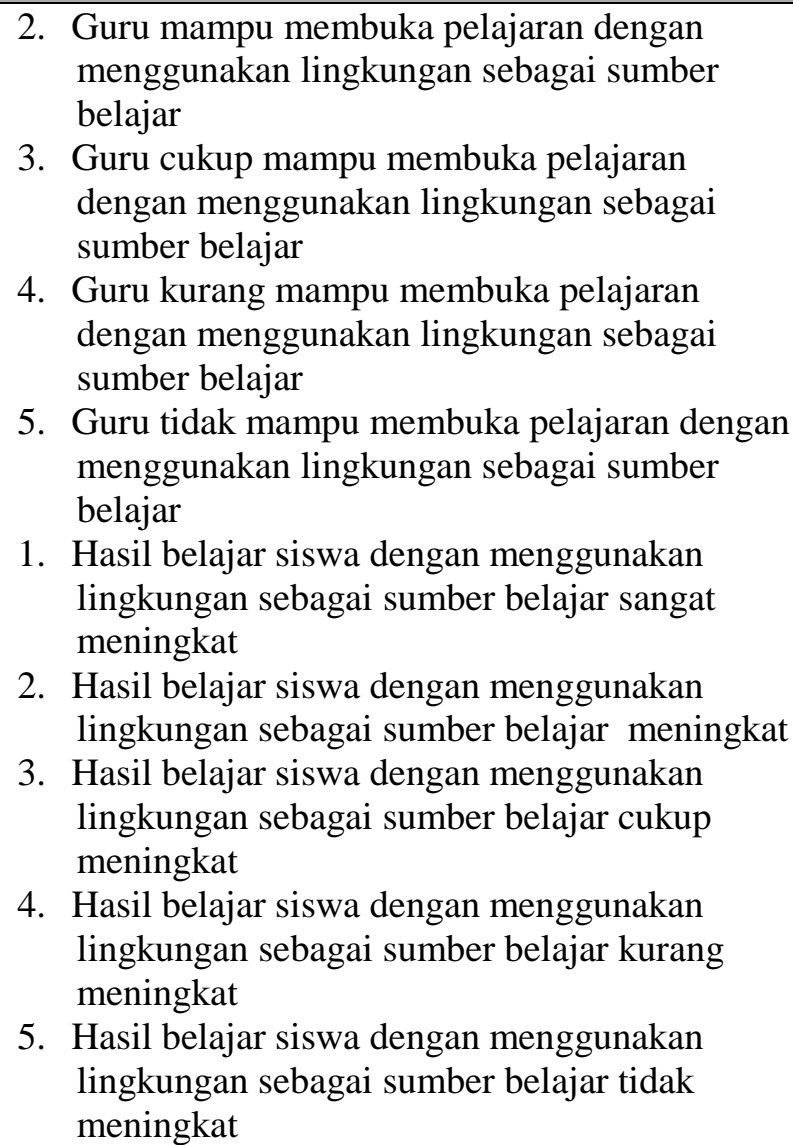 \\
\hline
\end{tabular}

$$
\text { Nilai Akhir }=\frac{\text { Jumlah Skor Perolehan }}{\text { Sor Maksimum }} \times 100
$$

Setelah data dalam penelitian ini terkumpul, selanjutnya dianalisis menggunakan analisis statistik deskriptif. "Metode analisis statistik deskriptif adalah cara pengolahan data yang dilakukan dengan jalan menerapkan rumus-rumus statistik deskriptif seperti angka rata-rata (Mean) untuk menggambarkan keadaan suatu objek tertentu sehingga diperoleh kesimpulan umum" (Agung, 2010:8) Tingkat kemampuan guru memanfaatkan lingkungan sebagai sumber belajar dapat ditentukan dengan membandingkan $\mathrm{M}(\%)$ atau rata-rata persen ke dalam PAP skala lima dengan kriteria sebagai berikut.

Tabel 03 Pedoman Konversi Skala Lima

\begin{tabular}{c|c}
\hline Persentase $(\%)$ & Kriteria \\
\hline $90-100$ & Sangat Baik \\
$75-89$ & Baik \\
$65-74$ & Cukup \\
$40-64$ & Kurang \\
$0-39$ & Sangat Kurang \\
\hline
\end{tabular}

Sumber: (Dantes Nyoman, 2009) 
Untuk mengetahui tingkat keberhasilan yang dapat dicapai pada sebuah tindakan, maka perlu ditentukan kriteria keberhasilan yang dapat diamati dari indikator-indikator ketercapaian. Kriteria keberhasilan penelitian ini dapat

diukur dari ketercapaian peningkatan kemampuan guru memanfaatkan lingkungan sebagai sumber belajar, setelah pelaksanaan FGD. Penelitian ini dikatakan berhasil apabila kemampuan guru dalam memanfaatkan lingkungan sebagai sumber belajar, secara individu telah mencapai rata-rata $\geq 75$, dan tingkat kemampuan guru memanfaatkan lingkungan sebagai sumber belajar sebesar $75 \%$ yang berada pada kategori baik.

\section{HASIL DAN PEMBAHASAN}

\section{HASIL}

Berdasarkan hasil observasi dan analisis kemampuan guru dalam memanfaatkan lingkungan sebagai sumber belajar pada prasiklus diperoleh rata-rata sebesar 65,19 dengan persentase sebesar 65,19\% dan setelah dibandingkan ke dalam PAP skala lima, maka tingkat kemampuan guru dalam memanfaatkan lingkungan sebagai sumber belajar pada tingkat kemampuan $65,19 \%$ yang berarti bahwa kemampuan guru memanfaatkan lingkungan sebagai sumber belajar pada prasiklus tergolong cukup. Untuk meningkatkan kemampuan guru dalam memanfaatkan lingkungan sebagai sumber belajar ditempuh dengan menerapkan FGD.

Pada siklus I tahap perencanaan disiapkan intrumen observasi kemampuan guru memanfaatkan lingkungan sebagai sumber belajar yang akan digunakan untuk menilai proses pembelajaran yang dilakukan oleh guru. Tahap pelaksanaan siklus I adalah membagi guru dalam dua kelompok kecil, peneliti memberi penjelasan tentang pemanfaatan lingkungan sekolah sebagai sumber belajar, guru menyusun skenario pembelajaran dengan memanfaakan lingkungan sekolah sebagai sumber belajar dalam diskusi kelompok, peneliti membimbing kelompok guru dalam menyusun RPP, wakil kelompok guru mempresentasikan skenario pembelajaran, peneliti memberi masukan terhadap RPP yang telah dibuat kelompok guru, guru melaksanakan skenario pembelajaran dalam proses pembelajaran yang sebenarnya, peneliti mengevaluasi kemampuan guru dalam mengimplementasikan skenario pembelajaran, dan dalam kelompok diskusi guru berbagi pengalaman terkait dengan pelaksanaan pembelajaran yang memanfaakan lingkungan sekolah sebagai sumber belajar.

Berdasarkan hasil obervasi kemampuan guru memanfaatkan lingkungan sebagai sumber belajar diperoleh rata-rata sebesar 70,37 dengan persentase sebesar 70,37\% dan setelah dibandingkan ke dalam PAP skala lima, maka tingkat kemampuan guru memanfaatkan lingkungan sebagai sumber belajar pada tingkat kemampuan 70,37\% yang berarti bahwa kemampuan guru memanfaatkan lingkungan sebagai sumber belajar pada siklus I tergolong cukup.

Berdasarkan hasil observasi dan analisis data siklus I terlihat ada peningkatan kemampuan guru memanfaatkan lingkungan sebagai sumber belajar. Sebelum dilaksanakan FGD nilai rata-rata kemampuan guru sebesar 65,19 dan setelah tindakan terjadi peningkatan menjadi 70,37. Hal ini disebabkan karena melalui FGD guru bisa berdiskusi dengan teman sejawat dalam hal pemecahan masalah baik dalam perencanaan, pelaksanaan, maupun tindak lanjut tentang pemanfaatan lingkungan sebagai sumber 
belajar. Kendala yang dihadapi pada siklus I adalah guru belum bisa mengubah kebiasaan mengajar dengan hanya memanfaatkan buku sebagai sumber belajar. Guru belum mampu menghubungkan materi yang diajarkan dengan lingkungan sekitar siswa. Guru belum mampu menangkap fenomena alam yang dapat dijadikan sebagai sumber belajar. Hal ini diatasi dengan memberikan cara menentukan lingkungan sebagai sumber belajar, memberikan waktu berdiskusi lebih banyak agar guru yang lebih mampu bisa memberikan informasi kepada guru-guru yang mengalami kendala. Melalui bimbingan dan diskusi yang dilakukan dengan optimal, akan dapat meningkatkan kemampuan guru khususnya dalam memanfaatkan lingkungan sebagai sumber belajar.

Pada siklus II tahap perencanaan disiapkan intrumen observasi pelaksanaan proses pembelajaran yang akan digunakan untuk menilai kemampuan guru memanfaatkan lingkungan sebagai sumber belajar oleh guru. Tahap pelaksanaan sama dengan pelaksanaan di sikus II. Berdasarkan hasil observasi pelaksanaan proses pembelajaran diperoleh rata-ratasebesar 78,52 dengan persentase sebesar 78,57\% dan setelah dibandingkan ke dalam PAP skala lima maka tingkat kemampuan guru dalam memanfaatkan lingkungan sebagai sumber belajar pada tingkat penguasaan 78,52\% yang berarti bahwa kemampuan guru memanfaatkan lingkungan sebagai sumber belajar pada siklus II tergolong baik.

Berdasarkan hasil observasi dan analisis data siklus II terlihat ada peningkatan dari siklus I. Sebelum dilaksanakan FGD nilai rata-rata kemampuan guru sebesar 65,19 dan setelah tindakan terjadi peningkatan menjadi 70,37. Kemampuan guru tersebut meningkat lagi pada siklus II menjadi 78,52. Hal ini disebabkan karena melalui diskusi dengan teman sejawat siswa mampu meningkatkan pemahaman dan kemampuan dalam pemanfaatan lingkungan sebagai sumber belajar. Perkembangan kemampuan guru dalam memanfaatkan lingkungan sebagai sumber belajar dapat dilihat pada tabel berikut.

Tabel 04 Rekap Perkembangan Kemampuan Guru Memanfaatkan Lingkungan Sebagai Sumber Belajar

\begin{tabular}{c|c|c|c|c}
\hline No & Siklus & Rata-Rata & Rata-Rata Persen & Kriteria \\
\hline 1 & Pra & 65,19 & $65,19 \%$ & Cukup \\
2 & I & 70,37 & $70,37 \%$ & Cukup \\
3 & II & 78,52 & $78,52 \%$ & Baik \\
\hline
\end{tabular}

\section{PEMBAHASAN}

Hasil yang diperoleh pada siklus II sesuai dengan penyajian data di atas menunjukkan bahwa kemampuan guru memanfaatkan lingkungan sebagai sumber belajar telah melampaui indikator keberhasilan, sehingga penelitian dihentikan sampai siklus II. Selama ini dalam proses pembelajaran guru hanya memanfaatkan buku paket sebagai sumber belajar.

Setelah diberikan tindakan dengan menerapkan FGD pada siklus I kemampuan guru memanfaatkan lingkungan sebagai sumber belajar dapat meningkat. Pada siklus II kembali dilaksanakan FGD yang lebih optimal dan terlihat adanya peningkatan kemampuan guru dalam memanfaatkan lingkungan sebagai sumber belajar. Pada siklus II guru diberikan penjelasan mengenai bagaimana memanfaatkan lingkungan sebagai sumber belajar secara lebih mendalam. Setelah guru diberikan tugas menyusun skenario 
pembelajaran yang memanfaatkan lingkungan sebagai sumber belajar, kemudian berdiskusi dengan teman sejawat melalui forum diskusi, akhirnya guru mampu menyusun skenario pembelajaran yang memanfaatkan lingkungan sebagai sumber belajar. Guru diberikan kelueluasaan berdiskusi dengan teman sejawat dipandu oleh peneliti. Guru yang memiliki kemampuan lebih memberikan masukan kepada guru yang kurang. Tampak mereka berdiskusi dengan antusias, sehingga guru mampu menyusun dan melaksanakan skenario pembelajaran yang memanfaatkan lingkungan sebagai sumber belajar.

Penelitian ini diperkuat oleh penelitian yang yang dilakukan Penelitian yang dilakukan oleh (Seriani, 2013) dengan judul Diskusi Terfokus Sebagai Upaya Meningkatkan Kemampuan Guru TK Kecamatan Buleleng Dalam Menyusun Instrumen Penilaian Pada Semester Genap Tahun Pelajaran 2012/2013. Hasil penelitian menunjukkan terjadinya perkembangan kemampuan guru TK dalam menyusun Instrumen penilaian, yang dibuktikan dengan awalnya rata-rata kemampuan guru adalah 54,16 kategori kurang, siklus I rata-rata nilai instrumen penilaian yang disusun oleh guru mencapai 74,78 dan pada siklus II rata-rata nilai dokumen instrument penilaian menjadi 88,92 .

Penelitian yang dilakukan oleh Siti (Aminah, 2015) dengan judul FGD untuk Meningkatkan Kemampuan Guru Memanfaatkan Lingkungan sebagai Sumber Belajar. Hasil penelitian menyimpulkan (1) FGD telah memberikan kesempatan yang luas kepada guru untuk dapat saling bertukar pikiran dan pengalaman, dan guru SDN di Wilayah Binaan IV Cawas Klaten merasakan adanya manfaat atas pelaksanaan diskusi kelompok terarah untuk memahami penyusunan skenario pembelajaran dengan memanfaatkan lingkungan sebagai sumber belajar; (2) $F G D$ mampu meningkatkan keterlibatan aktif guru dalam program supervisi (pembinaan) untuk meningkatkan kemampuan guru SDN di Wilayah Binaan IV Cawas Klaten; (3) FGD mampu meningkatkan kemampuan guru SDN di Wilayah Binaan IV Cawas Klaten terutama kemampuan guru dalam menyusun skenario pembelajaran untuk memanfaatkan lingkungan sebagai sumber belajar. Massi (2018) menyatakan bahwa FGD efektif untuk meningkatkan pengetahuan. Penelitian yang dilakukan oleh (Nurwahidah, 2019) menyatakan bahwa metode FGD dapat meningkatkan pemahaman dan pengetahuan. Penelitian yang dilakukan oleh Mashfufa, (2018:15) juga menyatakan bahwa "metode FGD efektif meningkatkan pengetahuan dan pemahaman orangtua dari hasil penelitian sebelum dengan sesudah FGD”. Selain Itu penelitian yang dilakukan oleh Safitri (2020) menyatakan bahwa terdapat pengaruh yang signifikan penerapan FDG terhadap self control pada remaja. Sari (2016) juga menyatakan bahwa FGD dapat diterapkan untuk meningkatkan pengetahuan. Berdasarkan penelitian tersebut dapat disimpulkan bahwa penerapan FDG efektif meningkatkan kemampuan dan pengetahuan.

\section{SIMPULAN DAN SARAN}

Berdasarkan hasil analisis dan pembahasan hasil penelitian dapat ditarik kesimpulan bahwa penerapan fokus group discussian (FGD) dapat meningkatkan kemampuan memanfaatkan lingkungan sebagai sumber belajar pada guru SD Negeri 1 Jinengdalem semester II tahun pelajaran 2019/2020. Hal ini terlihat dari rata-rata kemampuan guru dalam memanfaatkan lingkungan sebagai sumber belajar pada prasiklus sebesar 65,19, setelah tindakan pada siklus I terjadi peningkatan menjadi 70,37 dan 
meningkat lagi pada siklus II menjadi 78,52. Diharapkan agar guru mampu meningkatkan kemampuan dalam memanfaatkan lingkungan sebagai sumber belajar.

\section{DAFTAR RUJUKAN}

Afiyanti. (2008). Focus Group Discussion (Diskusi Kelompok Terfokus) Sebagai Metode Pengumpulan Data Penelitian Kualitatif Yati. Jurnal Keperawatan Indonesia, 12(1), $58-62$.

Agung, A. A. G. (2010). Metodologi Penelitian Pendidikan, Suatu Pengantar. Singaraja: Undiksha Press.

Aminah, S. (2015). FGD untuk Meningkatkan Kemampuan Guru Memanfaatkan Lingkungan sebagai Sumber Belajar.

Aswat. (2019). Efektivitas Pelaksanaan Metode Diskusi Kelompok Terpusat (Focus Group Discussion)Terhadap Motivasi Belajar Ips Murid Kelas V Sd Negeri Ii BoneBone Kota Baubau. Jurnal PAUD, 2(1), 1-27.

Bisjoe, A. (2018). Menjaring Data Dan Informasi Penelitian Melalui Fgd ( Focus Group Discussion ): Belajar Dari Praktik Lapang. Info Teknis Eboni, 15(1), 17-27.

Dantes Nyoman. (2009). Beberapa Rujukan Skenario Pembelajaran Berbasis Student Center Learning.

Ekowati, E. (2001). Stategi Pembelajaran Kooperatif. Modul Pelatihan Guru Terintegrasi Berbasis Kompetensi. Jakarta: Depdiknas.

Elfi, Y. (2017). Effectiveness Of Methods Focus Group Discussion (FGD) Parental Communication In The Role Of Adolescent Sexual Behavior In Sman 3 Kota Cirebon Year 2016. Jurnal Care, 5(3).

Istialina. (2016). Pemanfaatan Lingkungan Sebagai Sumber Belajar Pada Subtema Hewan Dan Tumbuhan Di Lingkungan Rumahku Kelas Iv Sd Negeri 3 Jeumpa Kabupaten Bireuen Unsyiah. Jurnal Ilmiah Mahasiswa Prodi PGSD, 1(1), 59-68.

Mashfufa. (2018). Efektifitas Fgd (Focus Group Discussion) Tentang Kekerasan Pada Anak. Jurnal Keperawatan, 9(1), 11-16.

Massi. (2018). Efektifitas Pemberian Edukasi Dengan Metode Video dan Focus Group Discussion (Fgd) Terhadap Tingkat Pengetahuan Pasien Dm Tipe 2 Di Klinikdiabetes Kimia Farma Husada Manado. Journal Keperawatan (e-Kep), 6(1), $1-6$.

Nurwahidah, D. (2019). Pengaruh Kepemilikan Manajerial Terhadap Nilai Perusahaan Dengan Struktur Modal Dan Profitabilitas Sebagai Variabel Intervening Pada Perusahaan Real Estate Di Bursa Efek Indonesia. Master Of Management Journal, $8(4)$.

Putra, A. (2017). Implementasi Pendekatan Pembelajaran Aktif, Kreatif, Efektif Dan Menyenangkan Ditinjau dari Hasil Belajar,. Jurnal Pendidikan Matematika, 5(2), $129-140$.

Safitri, dkk. (2020). Penerapan Focus Group Discussion Dengan Self Control Pada Remaja Pengguna Minuman Keras Oplosan Di Desa Monta Kabupaten Bima Tahun 2018. Jurnal Ilmiah Kesehatan, 10(1), 1-10.

Sari, E. (2016). Peningkatan Pengetahuan Ibu Tentang Upaya Preventif Penyakit Ispa Pada Balita Melalui Focus Group Discussion (FGD). Adi Husada Nursing Journal, 2(2), 32-34.

Seriani, N. G. N. (2013). Diskusi Terfokus Sebagai Upaya Meningkatkan Kemampuan Guru TK Kecamatan Buleleng Dalam Menyusun Instrumen Penilaian Pada Semester Genap Tahun Pelajaran 2012/2013. Penelitian Tindakan Sekolah.

Siregar. (2019). Pengaruh Pengungkapan Enterprise Risk Management , Intellectual Capital, Corporate Social Responsibility, Dan Sustainability Report Terhadap Nilai Perusahaan. Jurnal Bisnis Darmajaya, 5(2), 53-79.

Siregar, D. (2017). Penerapan Pendekatan Pembelajaran Aktif Inovatif Kreatif Efektif 
Dan Menyenangkan (Paikem) Pada Pembelajaran Matematika Kelas Iv Sd Negeri 010 Rambah. Jurnal Pemikiran Dan Pengembangan SD, 5(2), 743-749.

Siregar, S. (2018). Meningkatkan Kemampuan Guru Dalam Menerapkan Pembelajaran Kontekstual Melalui Focus Group Discussion (FGD) di SMK Negeri 1 Sirandorung Tahun Pelajaran 2017/2018. Jurnal Ilmu Pengetahuan Sosial, 5(14-19).

Situmorang, D. (2019). Pengaruh Focus Group Discussion Tentang Pelaksanaan Uji Kompetensi Terhadap Tingkat Kecemasan Mahasiswa. Jurnal Jumatik, 4(2), 220227.

Supriadi. (2015). Pemanfaatan Sumber Belajar dalam Proses Pembelajaran. Lantanida Journal, 3(2), 128-138.

Widiyati. (2019). Focus Group Discussion (FGD) untuk Meningkatkan Aktivitas dan Hasil Belajar Kompetensi Ketenagakerjaan Peserta Didik di SMP N 7 Purworejo. Indonesian Journal of History Education, 7(2), 146-153. 